\title{
Peningkatan Rasa Percaya Diri Melalui Pelatihan Public Speaking pada Siswa SMK N I Selo Boyolali
}

\author{
Sri Hartini ${ }^{\mathrm{a}, 1^{*}}$, Wahyuning Chumaeson ${ }^{\mathrm{b}, 1}$ \\ a Ilmu Komunikasi, Universitas Boyolali, Jl. Pandanaran No 405, Boyolali 57315, Indonesia \\ 1*dedemanieztenan87@gmail.com; ${ }^{2}$ wahyuningchumaeson@yahoo.co.id \\ * Koresponsendi penulis
}

ARTICLE INFO

Article history

Menerima: 29 Juni 2021

Revisi : 28 Juli 2021

Diterima: 29 Juli 2021

Kata Kunci

Training

Public Speaking

Self-Confidence

\begin{abstract}
Public speaking is a public speaking skill that can be trained. By continuing to do the practice of speaking in public effectively, a person can grow his self-confidence when speaking in front of many people. The importance of public speaking in one's life is to increase self-confidence. For this reason, this puIblic speaking training activity is carried out to achieve these goals for the students of SMKN 1 Selo Boyolali. This training activity includes material presentation about public speaking, discussion sessions, training to become an MC, speech training, storytelling sessions, and game sessions. This activity is expected to provide benefits for students of SMKN 1 Selo Boyolali in increasing self-confidence.
\end{abstract}

This is an open access article under the CC-BY-SA 4.0 license.

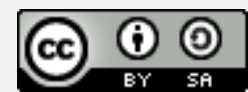

\section{Pendahuluan}

Komunikasi sudah menjadi kebutuhan setiap invididu di dunia ini untuk melakukan interaksi dan membangun hubungan yang harmonis. Komunikasi memiliki peranan yang sangat penting dalam penyampaian pesan atau informasi kepada penerima pesan agar pesan dapat tersampaikan dengan baik dan sesuai harapan. Dalam berkomunikasi, susunan kalimat dalam sebuah bahasa menjadi sangat penting untuk diperhatikan karena kalimat yang tidak tersusun dengan baik akan sulit dipahami oleh penerima pesan.

Peran bahasa menjadi sentral dalam aktivitas komunikasi dan interaksi dengan orang lain. Handayani (2008) pun menyebutkan bahwa melalui bahasa, anak-anak dapat tumbuh dan berkembang menjadi manusia dewasa yang mampu bergaul ditengah-tengah masyarakat[1]. Artinya, dalam melakukan aksi komunikasi dan interaksi, manusia akan bergaul ditengah masyarakat dengan berbagai keragaman budaya, bahasa, agama maupun kebiasaan-kebiasan yang berbeda. Dalam melakukan komunikasi, Helena (2008) mengatakan bahwa seorang pembicara itu mengembangkan gagasan-gafasannya dalam klaimat-kalimat[2]. Untuk itulah, penyusunan kalimat dengan bahasa yang tepat akan sangat menentukan kualitas komunikasi dengan orang lain.

Komunikasi dan interaksi yang terjadi antara individu dengan individu yang lain maupun dengan suatu kelompok, dapat memberikan sebuah ruang untuk berbicara dan bertukar pendapat dengan orang lain. Pembicaraan menjadi powerfull ketika konten yang disampaikan oleh public speaker dapat mempengaruhi pikiran audiens sehingga termanifestasi dalam tindakan[3]. Komunikasi yang terjadi secara terus-menerus baik melalui hubungan informal maupun hubungan 
formal, dapat memberikan rasa percaya diri pada seseorang dan dapat melatih keberanian berbicara didepan orang lain bahkan didepan umum.

Banyak orang yang merasa takut dan tidak percaya diri untuk berbicara didepan orang banyak sehingga lebih memilih diam ketika berada dalam sebuah forum. Hal ini seperti yang dituliskan dalam situs Jawapos.com bahwa menyampaikan pendapat didepan orang lain atau didepan umum adalah hal yang sulit[4]. Masalah seperti ini banyak ditemui di lapangan, misalnya saja ketika seorang siswa tidak mampu melakukan pidatonya dengan baik dikarenakan nervous saat maju didepan kelas. Dalam kasus yang lain misalnya, mahasiswa yang takut ketika berhadapan dengan Dosen Pembimbing sehingga tidak mampu menjelaskan rencana penelitiannya. Bahkan banyak yang kemudian kehilangan kesempatan menjadi pemandu acara kegiatan karena mereka tidak percaya diri berbicara didepan umum dan perannya harus digantikan dengan orang lain.

Kemampuan berbicara di depan umum atau yang kita kenal dengan kemapuan public speaking perlu untuk terus dikembangkan dan dilatih, jika tidak maka dapat menimbulkan ketakutan berbicara didepan umum selamanya. Untuk mendapatkan kepercayaan diri ketika berbicara di depan audiens adalah dengan cara berlatih, tidak ada cara instan untuk mendapatkan kemampuan public speaking[5]. Menurut Sirait (2008), public speaking didefinisikan sebagai seni yang menggabungkan semua ilmu dan kemampuan yang kita miliki. Memberanikan diri di depan umum berarti siap menyampaiakan pesan kepada orang-orang yang memiliki latar belakang berbeda[6]. Sebagai seni, keterampilan berbicara merupakan seni keterampilan yang elegan, ekspresif dan kreatif[7].Dalam situs glints.com, juga dikatakan bahwa kemampuan dalam public speaking dapat meningkatkan kepercayaan diri. Situasi ini dapat menggambarkan bahwa berbicara didepan umum merupakan kemampuan yang memerlukan latihan[8].

Tidak percaya diri dalam berbicara didepan umum menjadi permasalahan utama yang dihadapi oleh siswa-siswi di SMKN 1 Selo Boyolali. SMK ini merupakan satu-satunya Sekolah Kejuruan Pariwisata di Kabupaten Boyolali yang memiliki spesialisasi jurusan Usaha Perjalanan Wisata (UPW), dan Akomodasi Perhotelan (APH). UPW dan APH sangat berkaitan erat dengan dunia kerja yang berhubungan langsung dengan banyak orang daripada Jurusan Teknik Sepeda Motor (TSM). Sebagai Sekolah Kejuruan Pariwisata dan Perhotelan, siswa-siwi dituntut untuk mampu berkomunikasi dengan baik dalam menghadapi dunia kerja. Permasalahan yang dihadapai siswa-siwi di SMKN 1 Selo ini adalah kurangnya percaya diri dalam berkomunikasi didepan umum, seperti dalam menyampaikan gagasan forum, mengambil peran dalam kegiatan sekolah seperti MC, maupun berbicara didepan kelas.

Berbagai permasalahan diatas tentunya menjadi kendala dalam berkomunikasi dan mengembangkan potensi diri. Public Speaking berperan dalam penyampaian informasi dan teknik komunikasi yang sangat dibutuhkan oleh semua orang dalam berbagai bidang kegiatan[9]. Public Speaking perlu dipelajari untuk berkomunikasi dan berinteraksi satu sama lain[10]. Maka kegiatan platihan puIblic speaking bagi siswa-siswi SMKN 1 Selo perlu untuk dilakukan sehingga dapat membantu dan memberikan solusi yang dihadapi dalam meningkatkan rasa percaya diri para siswa untuk berbicara didepan umum. Melalui kegiatan Pelatihan Public Speaking ini diharapkan tidak ada lagi siswa-siswi yang merasa minder dan kecil hati jika harus berhadapan dengan orang didepan umum dalam kegiatan-kegiatan yang diseleggarakan. Selain itu, siswa-siswi SMKN 1 Selo juga siap dan percaya diri jika diminta memandu acara sekolah.

\section{Metode}

Pengabdian Masyarakat dalam Kegiatan Pelatihan Public Speaking ini dilakukan dalam upaya untuk meningkatkan rasa percaya diri pada Siswa-siswi SMKN 1 Selo Boyoali. Kegiatan ini dilakukan melalui beberapa pelatihan langsung kepada siswa-siswi peserta kegiatan. Adapun kegiatan pelatihan yang dilaksanakan adalah sebagai berikut:

\section{Memberikan Pemaparan tentang Pentingnya Public Speaking}

Dalam sesi ini, pelaksana pengabdian memberikan pemaparan tentang pentingnya public speaking dalam meningkatkan rasa percaya diri. Orang yang ingin memiliki kemampuan berbicara didepan umum dengan lancar maka harus rajin berlatih. Betapa pentingnya menguasai public 
speaking dalam dunia kerja, dimana kita bisa tampil begitu professional dan elegan saat tampil didepan umum. Semua pembekalan tentang public speaking diharapkan mampu memberikan manfaat dan motivasi kepada para siswa-siswi sehingga tidak lagi merasa malu-malu untuk tampil didepan umum.

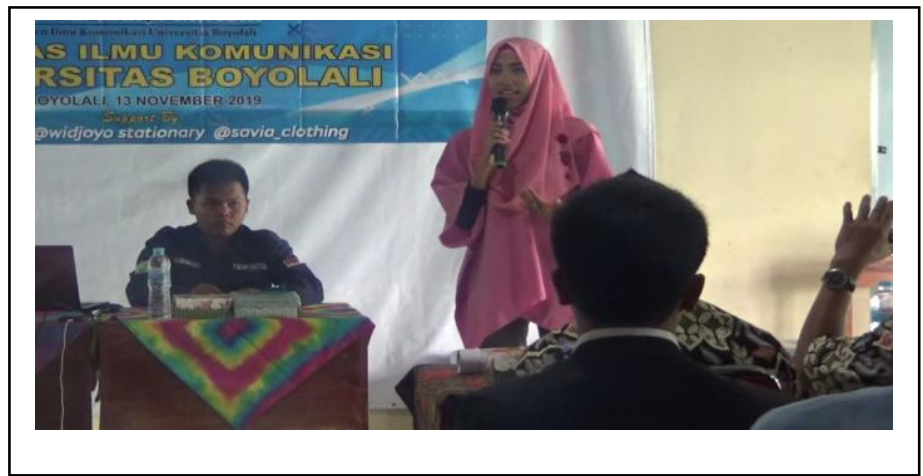

Fig. 1. Pemaparan Materi

\section{Mengadakan Diskusi}

Public Speaking merupakan kemampuan berbicara yang dapat dilatih sehingga dapat memunculkan keberanian bagi seseorang untuk mengungkapkan pendapatnya. Metode diskusi dapat memberikan pancingan bagi siswa untuk berani mengungkapkan apa yang ada didalam pikirannya. Dalam kegiatan pelatihan ini, pelaksana pengabdian memberikan berperan sebagai narasumber yang akan menjawab pertanyaan dari para siswa. Sesi diskusi dilakukan dengan metode tanya jawab, dimana siswa diberikan kesempatan untuk bertanya terkait materi yang menjadi fokus dalam sesi diskusi yaitu cara menghilangkan rasa takut ketika berbicara didepan umum. Sesi diskusi ini berlangsung selama 20 menit dengan beragam pertanyaan dan feed back nya. Berdasarkan acara yang berlansung, para siswa SMKN 1 Selo mencoba untuk memunculkan keberaniannya dengan bertanya kepada pemateri, meskipun dengan suara gemetar saat berbicara, hilang fokus dan sebagainya. Namun, akhirnya para siswa mampu mengontrol diri sehingga kalimat-kalimat yang diucapkan lebih teratur. Sesi diskusi ini sangat penting sehingga diberikan porsi tersendiri.

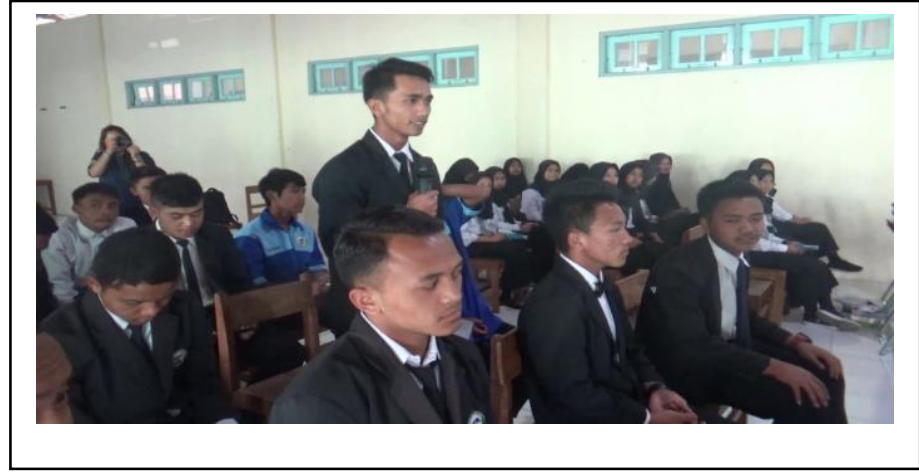

Fig. 2. Siswa mengajukan pertanyaan

\section{Memberikan Pelatihan MC}

MC merupakan salah satu elemen penting yang tak terpisahkan dalam ranah public speaking. Kemampuan seorang MC dalam berbicara didepan umum dihasilkan dari latihan yang tiada henti. Dalam kegiatan pelatihan ini, ada tiga metode yang dilakukan pelaksana pengabdi 
yaitu, petama, memberikan bekal materi tentang pemandu acara formal dan non formal dan memberikan contoh prakteknya. Kedua, menampilkan beberapa contoh MC formal dan non formal di layar proyektor sehingga dapat memberikan gambaran kepada para siswa sebelum langsung mempraktekkannya. Ketiga, meminta kepada para siswa untuk menunjukkan keberaniannya dengan praktek langsung.

Kendala yang muncul dalam pelatihan MC ini, para siswa masih merasa malu-malu untuk mencoba sehingga pelaksana pengabdi harus menunjuk siswa secara random untuk praktek sebagai pemandu acara. Pelatihan ini menjadi bekal untuk mereka menumbuhkan rasa percaya diri bahwa ternyata mereka punya potensi.

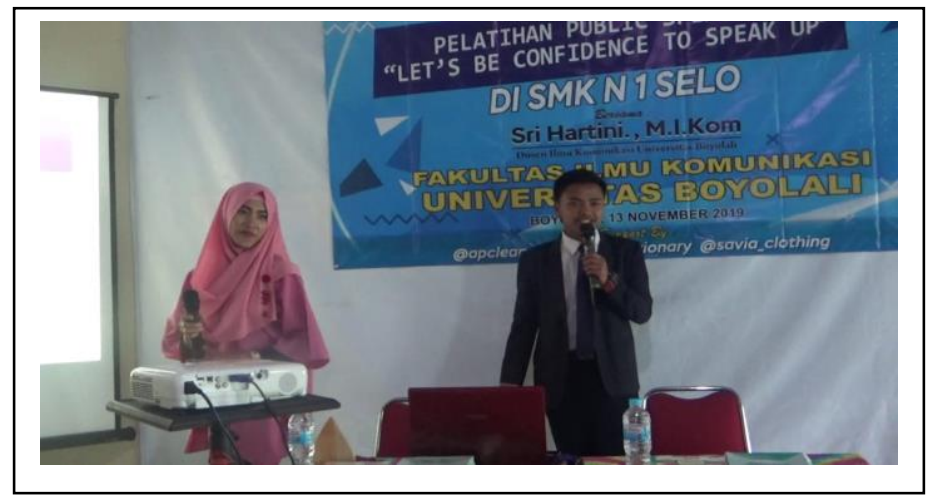

Fig.3. Salah satu siswa praktek MC

\section{Memberikan Pelatihan Pidato}

Pidato juga merupakan salah satu ruang lingkup dari public speaking, untuk itu pidato menjadi salah satu materi yang perlu diberikan dalam pelatihan ini. Pemaparan dan contoh dalam berpidato dapat memberikan pengalaman yang berbeda kepada para siswa ketika mengetahui bahwa pidato tidak selalu dibawakan dengan serius. Yang kemudian disampaikan dalam pelatihan ini adalah bahwa pidato juga bisa disampaikan dengan gaya bahasa yang luwes, dan menghibur agar pesan yang disampaikan dapat diterima dengan senang hati oleh pendengar. Dalam sesi ini, pelaksana pengabdi juga meminta para siswa untuk maju ke depan kelas mempraktekkan pidato.

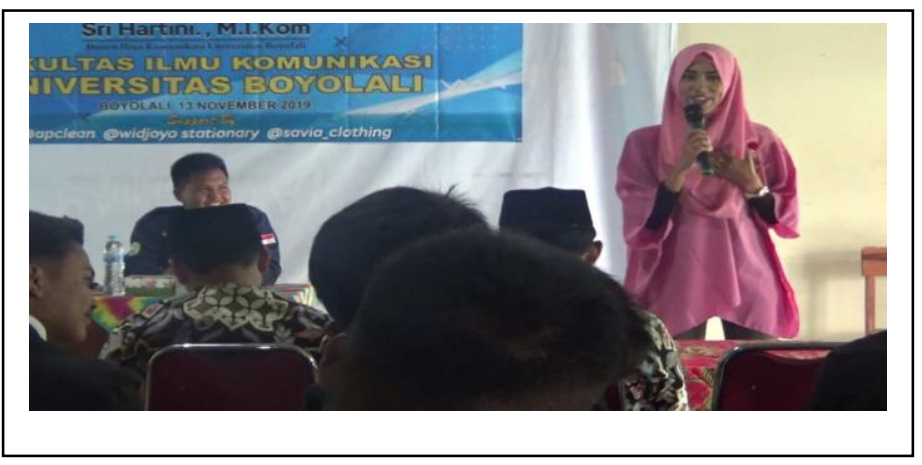

Fig. 4. Pemberian Contoh Pidato

\section{Memberikan Sesi Bercerita}

Dalam sesi bercerita ini, pelaksana pengabdian memberikan pemaparan bahwa tidak semua orang mampu bercerita dengan baik dan runtut bahkan hanya sekedar menceritakantentang pengalaman hidupnya sendiri. Tidak percaya diri didepan orang banyak bisa membuyarkan apa yang ada didalam pikiran, bahkan yang telah dirangkai dengan baik sekalipun. Dalam sesi bercerita ini, pelaksana pengabdian memberikan pemaparan bagaimana harus bercerita dengan menarik kepada orang lain agar pendengar tertarik terhadap cerita kita. Kegiatan ini dilakukan dengan harapkan bahwa para siswa SMKN 1 Selo dapat berbicara didepan umum tanpa ragu dan tanpa malu ketika harus berbagi cerita tentang pengalaman hidup yang paling berkesan. Dari sesi 
bercerita ini, pelaksana pengabdian memberikan motivasi bahwa para siswa memiliki cerita yang menarik dan layak dibagikan sehingga mereka berani untuk bercerita.

Dalam sesi ini, sudah ada beberapa siswa yang berani maju ke depan kelas untuk bercerita dan berbagi tentang berbagai pengalaman seperti pengalaman saat masuk pertama kali masuk ke SMKN 1 Selo, pengalaman tentang hobinya yang menghsilkan uang, pengalaman tentang hal yang membuatnya malu karena gagap teknologi. Artinya, para siswa telah berani membuka diri, mencoba menggali potensi dan keberanian dengan mampu berkomunikasi didepan orang banyak. Hal ini sangat penting untuk terus dikembangkan agar rasa percaya diri terus meningkat.

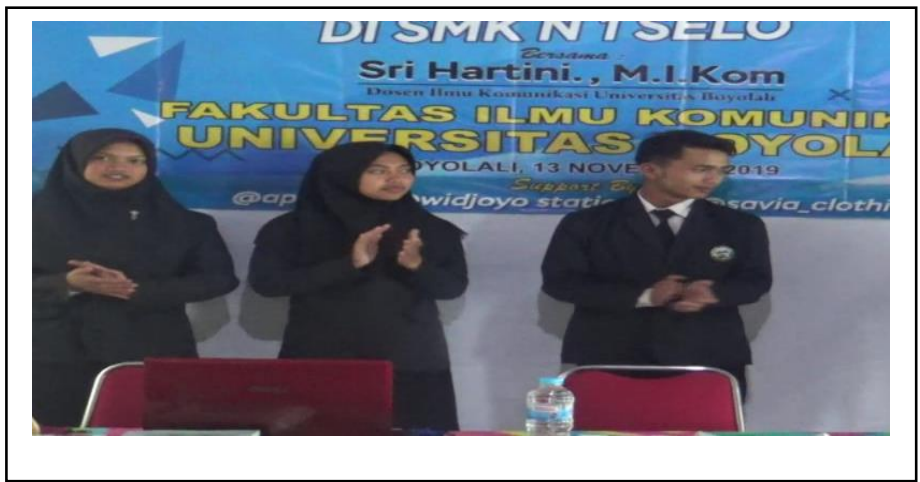

Fig.5. Para Siswa berani bercerita

\section{Memberikan Permainan atau game}

Sesi terakhir dalam kegiatan pelatihan ini adalah sesi permainan atau game. Setelah serangkaian kegiatan yang dilakukan dalam pelatihan public speaking, pelaksana pengabdi melakukan refresh terhadap para siswa melaui sebuah permainan. Sesi game dalam pelatihan ini memiliki tujuan untuk menghilangkan rasa malu diantara teman ketika harus melakukan kerjasama dan menjaga koslidan tim. Dalam permainan ini, para siswa diajak untuk menjaga kekompakan dan bekerjasama.

Adapun cara bermainnya adalah, pelaksana pengabdi meminta kepada panitia untuk membuat dua lingkaran diatas lantai. Setelah itu, pelaksana pengabadi menjelaskan aturan mainnya, dalam hitungan ketiga, semua siswa harus masuk ke dalam lingkaran tersebut. Jika ada yang tidak masuk ke dalam lingkaran, maka akan mendapatkan punishment dari panitia. Para siswa terlihat sangat aktif dan semangat dalam sesi ini. Dari sesi permainan ini juga dapat melatih kebaranian, dimana para siswa tidak malu-malu memanggil nama temannya, tidak malu ketika harus berteriak memberi komando kepada teman-temannya untuk segera memasuki lingkaran. Keberanian, percaya diri, tidak merasa malu menjadi pelajaran baru bagi mereka.

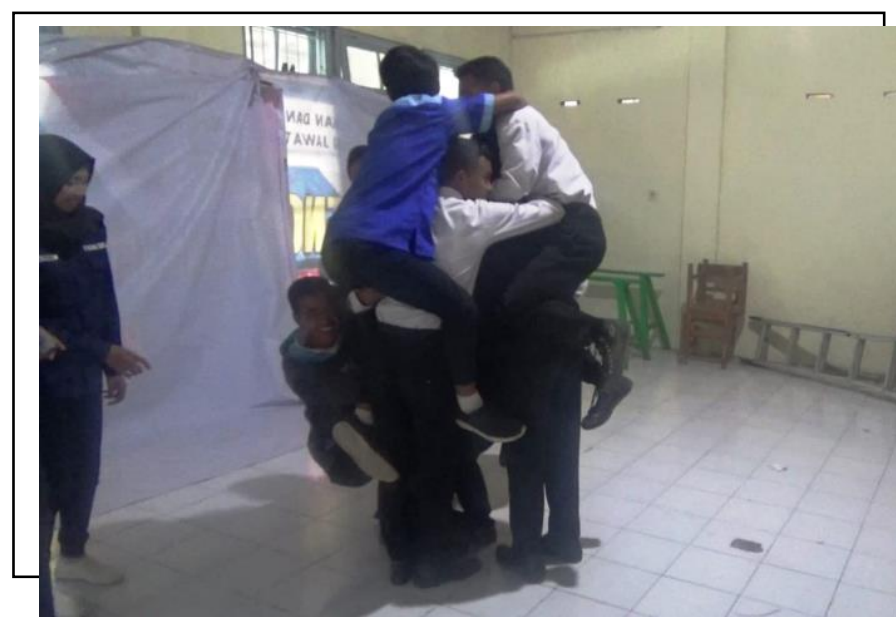

Fig.6. Sesi Permainan

Hartini dan Chumaeson (Peningkatan Rasa Percaya Diri Melalui Pelatihan Public Speaking pada Siswa SMK N I Selo Boyolali) 


\section{Hasil dan Pembahasan}

Kegiatan pelatihan public speaking ini adalah kegiatan yang pertama kali diikuti bagi para siswa SMKN 1 Selo sehingga mereka sangat antusias dalam mengikuti kegiatan. Kegiatan pelatihan ini dilakukan selama 4 jam yang dimulai pada pukul 09.00-13.00 di Ruang Aula SMKN 1 Selo. Pelatihan public speaking ini dilakukan melalui berbagai macam kegiatan didalamnya seperti pemaparan materi, diskusi, praktek sebagai MC, praktek pidato, story telling, dan sesi permainan.

Kemampuan berbicara didepan umum sangat penting dimiliki oleh setiap orang karena dapat menunjang karir di masa depan. Melalui kegiatan pelatihan ini, pelaksana pengabdian menekankan bahwa para siswa SMKN 1 Selo harus terus melatih diri untuk menyampaikan gagasan atau ide mereka ke publik. Dengan demikian, rasa percaya diri akan terus meningkat. Karena mampu berkomunikasi didepan umum memerlukan latihan dan tidak bisa instan.

Adapun keberhasilan yang dicapai dari kegiatan pelatihan pelatihan public speaking dalam upaya meningkatkan rasa percaya diri para siswa SMKN 1 Selo adalah sebagaia berikut:

1. Para siswa SMKN 1 Selo mampu menunjukkan pemahaman mereka terkait pengetahuan baru yaitu tentang Public Speaking dan pentingnya public speaking dalam menunjang karir di masa depan. Para siswa memberikan respon yang antusisas dengan aktif bertanya dan terlibat dalam proses diskusi. Hal ini membuktikan bahwa para siswa SMKN 1 Selo dapat menerima informasi baru yang diberikan. Keingintauannya mampu mampu mengalahkan rasa takut dan malu ketika harus bertanya kepada pemateri.

2. Melaui Pelatihan public speaking, para siswa SMKN 1 Selo dapat menggali potensi diri mereka dan mempraktekkan langsung didepan forum pelatihan. Para siswa SMKN 1 Selo menyadari bahwa mereka memiliki potensi. Melalui kegiatan ini dapat menjadi sarana awal bagi mereka untuk melatih potensi diri mereka dengan mempraktekan langsung baik sebagai MC, berpidatao maupun bercerita.

Evaluasi dari kegiatan pelatihan ini tidak dilakukan secara menyeluruh diakhir kegiatan, akan tetapi dilakukan pada setiap pos kegiatan berakhir yaitu dengan melakukan praktek secara langsung pada setiap sesi pelatihan. Hal ini bertujuan untuk memberikan kemudahan pada siswa dalam mengikuti kegiatan pelatihan pada setiap tahapan kegiatan. Hasil pelaksanaan kegiatan pelatihan public speaking ini telah menunjukkan perubahan positif pada para SMKN 1 Selo sebagai khalayak sasaran kegiatan ini dalam hal pemahaman tentang keterampilan berbicara di muka umum dalam upaya meningkatkan rasa percaya diri.

\section{Kesimpulan}

Kemampuan berbicara didepan umum secara efektif itu dapat dilatih. Melalui kegiatan public speaking, maka rasa percaya diri dapat meningkat seiring dengan latihan yang terus dilakukan. Rasa percaya diri yang dimiliki seseorang dapat meningkatkan kualitas hidup mereka dimasa depan sehingga kegiatan pelatihan public speaking penting untuk dilakukan.

Public speaking merupakan hal baru bagi para siswa SMKN 1 Selo. Mereka sudah mengenal istilah MC, pidato, diskusi, presentasi, bercerita namun mereka belum memahami bahwa istilah-istilah tersebut merupakan ruang lingkup dari public speaking. Melalui kegiatan pelatihan public speaking ini, para siswa SMKN 1 Selo menjadi paham akan pentignya kemampuan berbicraa didepan umum. Pelatihan ini memberikan banyak pengetahuan baru dalam mengembangkan potensi diri mereka. Para siswa SMKN 1 Selo sangat antusias mengikuti kegiatan pelatihan ini hinga selesai karena dalam kegitan ini, mereka memiliki kesempatan untuk menunjukkan kemampuan mereka dalam public speaking. 


\section{Ucapan Terimakasih}

Ucapan terimakasih penulis haturkan kepada SMKN 1 Selo Boyolali sebagai mitra Kegitaan Pengabdian Kepada Masyarakat ini.

\section{Daftar Pustaka.}

[1] Handayani, Putri Ayu. 2008. Pentingnya Peningkatan Keterampilan Berbicara Pada Anak Usia Dini Melalui Metode Bercakap-Cakap. Bandung: Sekolah Sekolah Tinggi Keguruan Dan Ilmu Pendidikan.

[2] Olii, Helena. 2008. Public Speaking. Cetakan Ketiga. Jakarta: PT Macana Jaya Cemerlang

[3] Sirait, C. B.2016. The Power Of Public Speaking. Jakarta: Elex Media Komputindo

[4] https://www.jawapos.com/lifestyle/29/09/2019/4-tips-agar-berani-bicara-di-depan-banyakorang/

[5] Hojanto, O. 2016. Public Speaking Mastery.Jakarta: Gramedia Pustaka Utama.

[6] Sirait, C.B. 2008. The Power of Public Speaking: Kiat Sukses Berbicara di Depan Publik. Jakarta: Gramedia Pustaka Utama.

[7] https://glints.com/id/lowongan/kemampuan-public-speaking/\#.YLSCY7czbIU

[8] Iskandar, D. (2014). Retorika sebagai seni berbicara.Mentari: Majalah Ilmiah Universitas Muhammadiyah Aceh.

[9] Puspita, R.Y.2017.Cara Praktis Belajar Pidato, MC, dan Penyiar Radio.Yogyakarta: Komunika.

[10] Dewi, Fitriana Utari. 2018.Public Speaking: Kunci Sukses Berbicara di depan publik. Teori dan Praktik.Cetakan Keempat.Yogyakarta: Pustaka Pelajar. 